\title{
Promotion of Public Participation in School Environment
}

\author{
Phillip F.A Matshe \\ Department of Post Graduate Studies in Education \\ North West University, South Africa \\ Email address: phillip.matshe @gmail.com
}

Victor J. Pitsoe

Department of Educational Leadership and Management, College of Education, University of South Africa, South Africa Email address: Pitsovj@unisa.ac.za

\section{Doi:10.5901/mjss.2013.v4n13p643}

\begin{abstract}
This article seeks to explore the promotion of public participation in school-based management. It shows the dire need of the public in running the affairs of education of their children and how their involvement may improve the quality of education in South Africa. In this article, we argue that public participation in education is a constitutional requirement which must be treated with care and respect by those with interest for quality public education. We depart from the assumption that the education system will lose value if parents as key stakeholders can be left behind in decision making processes. Involvement of ordinary people in our country is a constitutional right and adherence to this important democratic right shows that indeed education is taken very seriously as a societal activity. In order to fully understand the complexity of this phenomenon, this article presents a conceptual framework ranging from parents' participation through to participative management theories.
\end{abstract}

Keywords: public participation, co-operative management, education system, School governance, democracy.

\section{Introduction}

It is perhaps appropriate and fitting to start this discourse by indicating that today's approach towards development has a close link with the concept "public or community participation". As Roberts (2003:67) observes, "the notion that communities should have a say and be empowered to exert direct influence in decisions that would impact on their social, material and environmental well-being is virtually undisputed in the development and democratisation debate to the point of becoming accepted as a basic need and democratic right." It is no longer the sole duty of those in authority to make decisions, but the public must also participate. Yet, according to Roberts (2003:67), notwithstanding the wide acceptance of the need for and benefits of participation in development, the going consensus becomes fuzzier with regard to the best way to achieve participatory governance in practice.

More often than not, despite good intentions, the practise of participatory democracy still falls short of its ideals and expectations. A plethora of literature on the theory and practice of public participation currently exists, offering a variety of case studies, best practises and guidelines. However, this vast literature seems not to be reaching its intended objectives. Put in a nutshell, our thesis amounts to this. Public participation in education is a constitutional requirement which must be treated with care and respect by those with interest for quality public education. In doing so, we: (1) provide background information; (2) look at the overview of the concept public participation; (3) investigate the origins of participatory theory; (4) explore participative management theory (5) argue parents as partners; and lastly (6) examine the challenges and benefits of parental involvement.

\section{Background Information}

We start from the simple observation that if parents have been made to believe that education is the sole responsibility of the school, then they are apt to withdraw from school activities and leave education on the shoulders of the teaching personnel. However, if they are made aware of the vital link and interconnectedness that exist between education at home and education in the school, they will wish to be involved in those activities that promote their children's successs 
at school (Van Wyk \& Lemmer, 2009:7). Before 1994, there was never such connection because school governance and management has been the sole responsibilities of both the principals and teachers. Parents were not involved in educational related issues especially on issues such as governance, finances and management (Clase et al, 2007:167). This situation was triggered by number of factors which include but not limited to lack of policies that could reinforce participation in the management of schools.

It is noteworthy to indicate that the political system in South Africa did not allow participation of stakeholders on matters related to school governance, and that has been the case with black schools. Over and above, the way in which the education system was designed where the management was hierarchical from top to bottom and very authoritarian (Christie, 1991:38). The parent's representatives, at best only participated in an advisory capacity regarding the governance of their schools (Christie, 2001:34-48). Hartshorne (1999:25) in support of scholars who are condemning the evil of apartheid education argued that the apartheid education was specifically meant for black children to serve their own communities. As a result, they did not form part of the mainstream education system in South Africa.

The poor education standard received by blacks as well as the issue of non-representation in the governance of schools made black communities to resist everything from the system. This include the rejection and refusal to use Afrikaans as a medium of instruction and that led to the class boycott and students' appraisal of 1976 (Christie, 2001:240). In 1985, a state of emergency was introduced, and that gave birth to the complete collapse of black education in quite larger areas of black communities. For example, in Soweto, parents formed a committee, called Soweto Parents' Crisis Committee to organize a national conference to address the exclusion of blacks in the decision-making process regarding education. The result of the conference recommended for the formation of a strong negotiating team called National Education Crisis Committee (NECC). The NECC strived for the creation of an education system along the line of people's education and the active involvement of black people in matters of governance (Cosser, 1991:59). This move forced the State to take notice of the NECC, and the Department of Education and Training (DET) lost its authority in many of the urban schools as there was chaos which could not be easily managed by the government.

The sensitivity of the matter pressurized the government of the day to request the Human Science Research Council (HRSC) to investigate the problem of the education system and to recommend possible solutions. Then the HRSC formed a commission, called De Lange Commission which, in their report, recommended for the restructuring of education system such that decision-making and management to be designed in such a way that all the interested and affected parties in all spheres of government i.e. local, regional and national level participate (Cosser, 1991:57). This initiative serves as the good foundation for change in the education system where black communities were allowed to participate in decision making and governance of black schools (Human, 1998:12). This was further confirmed by the democratic dispensation through the Constitutional Act 108 of 1996 which appealed for the transformation of the education system and ensured that everyone has the right to participate in the governance of schools (RSA, 1996).

\section{Overview of the Concept Public Participation}

The point to begin with is to acknowledge that different scholars clarify concepts differently considering the meaning attached to it. The reasoning behind it may be the fact that concept clarification is not separated from the context within which it is defined. This view, acknowledges the influence of one's context in clarifying concepts or giving meaning to one's contextual realities (Maile, 2002). The term "public participation" describes a variety of relationships between the implementing agency and its stakeholders. The nature of a planned public participation process will depend on what is planned and the goal of the initiative. In some instances, the public only needs to be informed about certain initiatives or aspects of it. Other initiatives require public opinions and views. Wood (2003:147) asserts that public participation is a process of engagement, where people are enlisted into the decision process to distribute to it. Participation methods provide for exchange of information, predictions, opinions, interests and values. In his view, Birch (2002:71) feels that "public participation is no longer a voluntary exercise but an integral part of our democratic society. It is aimed at improved decision-making." He contends that this involvement can take many forms and can derive from either a legal right to participate at particular stages of a process or from an invited side.

Carrim (2001:26) defines public participation as a process in terms of which the public is systematically and proactively afforded an opportunity to share their knowledge and concerns on developments, programmes and policies with a view to the promotion of informed and generally acceptable authority decisions. However, Aucamp (2009:49) argues for public participation as a process leading to a joint effort by stakeholders, technical specialists, the authorities and the proponents who work together to produce better decisions than if they had acted independently.

The definitions above have important similarities: 
- Public participation is a process which allows I\&APs an opportunity to share their issues /concerns /questions /contributions regarding the proposed project and to put alternatives forward.

- Public participation is also a process which assists to provide authorities with information to be able to make decisions.

Admitedly, community participation is a familiar concept in the development, humanitarian and education sectors, and increasingly a standard feature of programme design (UNESCO, 2009). On one hand, community participation refers to both the processes and activities that allow members of an affected population to be heard, empowering them to be part of decision-making processes and enabling them to take direct action on education issues (UNESCO, 2009). Beetham (1992), on the other hand, asserts that participation may be a vague term and its advocates often rely on two key arguments about its value and on what it makes for justice in decision-making and the influence on collective decision which has an educative value. Through participation people should gain something at the end of their involvement. As Midgley et al. (1986:23) note, the notion of popular participation and community participation are interlinked. The former is concerned with broad issues of social development and the creation of opportunities for the involvement of people in the political, economic and social life of a nation." The latter connotes the direct involvement of ordinary people in local affairs".

UN document (1981:5) defines community participation as the creation of opportunities to enable all members of a community to actively contribute, influence the development process and to share equitably in the fruits of development. In addition, Molopo (2000:9) draws attention to the research that confirms that parental participation, despite the educational background or social position of the parents, is an essential component for successful education and teaching at school level. Parental participation in South African Schools was confirmed through the promulgation of an act which speaks for the participation of parents, that is, Act 84 of 1996, in an organised structure called SGBs (School governing bodies). Clase et al. (2007:247) contend that for members of governing bodies to participate in government policy in South Africa can be complex because the term has different meanings for different people against the background of cultural diversity in South Africa. Sayed and Carrim (1997:95) distinguish four ways of participation in the governance and management of Schools in South Africa:

- Community participation that points to common and shared aspects of human interaction. An unqualified allegiance to community participation becomes increasingly difficult because communities become increasingly fragmented on the grounds of class, sex, race and nationality.

- Participation as partners, which implies that legal partners obtain the right to participate in educational processes.

- Regulated (co-operative) participation, where constraints are placed on the nature of participation in an attempt to move away from the potential antagonism that can be caused through participation or the participation of partners.

- Weighted participation, according to which certain groups of participants have more rights than others, for example, parental representatives which, in the present situation in South African Schools would constitute the majority in SGBs.

\section{The Origins of Participatory Theory}

It would be apposite to begin this section by exploring the origin of the concept "public participation". The idea of public participation is old and has a very rich history - it dates back to Stone Age. Among others, its origins within the local government sphere can probably be traced to three root sources:

\subsection{Participation as good development project practice}

As Abbot (1996:213) writes, "participation was first used in the 1950's by social activists and project field workers as a necessary dimension of development". He submits that the World Bank, internationally, as well as the Development Bank of Southern Africa have since taken the notion of participation as a prerequisite for successful project implementation to heart. It has now become common practice to include some or the other forms of public participation in the implementation of infrastructure projects within the local government environment. A large amount of case studies tend to focus on project specific participation and it is arguably the most well known participation framework of reference (World Bank source book, 1995). 


\subsection{Participation as good governance}

Abbot (1996:213) avers that governance is a term that refers to the nature of the relationship between the state and civil society. He further submits that participation within the context of good governance has its origins from within Western democracies since the 1980's and 1990's. Falling voter turn out (the so-called democratic deficit) and a general sense of disillusionment with particularly local government resulted in a rethink in the way civil society can be re-engaged. He made reference to a powerful late 1990's article that has shown how voter turn out in almost all Western democracies are experiencing rapid decline. South Africa is, according to IDHSA pre-election polls, experiencing the same perception trends, possibly indicating that the healthy state of participation in local democracy after 1994 will decline in line with other democratic societies. The thread presented to democracy when few bother to vote is self-evident.

The causes of this democratic disengagement is varied but commonly based on the perceptions of oppressive, unresponsive and inefficient bureaucracies, in addition to a sense of powerless and marginalised local political structures within the state (Osborne \& Gaebler (1993:134). Strong links also exist with the crisis of the welfare state in Western democracies. A common feature of the dramatic public sector reforms in the developed world in the last decades has been serious attempts to address what has become known as the "crisis" in local democracy (Geddes \& Martin, 1997). Widespread disengagement and disinterest of key groups and social and economic exclusion prompted a range of initiatives to re-establish the legitimacy of local councillors, combat social exclusion and improve participation in representative democracy (Kooiman, 1993). New forms of democratic participation have been the result, e-governance and real time polling mechanisms to name a few. It has also given rise to completely new institutions of governance, illustrated by the rapid increase of the residential community association phenomena, increases in community development corporations and increasing complexity in service delivery configurations.

\subsection{Participation as political empowerment}

Originating from economic development theory and theories of development, the empowerment approach to community participation is located within the radical paradigm of alternative development and manifests itself in the mobilisation of popular political power (Dilger, 1994:132). With intellectual origins in neo-Marxist writers such as Freire and Castells, this approach locates participation within a wider political struggle that links the condition of under-development with access to political power (Dilger, 1994:132).

In South Africa, Patrick Bond is the most prominent articulator of ideas within the empowerment tradition (Bond, 2001). Originally, participation within this tradition found expression in popular resistance movements within South America, Asia and South Africa. The United Democratic Front (UDF) in South Africa being a typical example of the type of movements to emerge within the context of popular urban resistance movements with a political empowerment agenda (Seekings, 2000; Mayekiso,1976). At the local government and community interface, participation within this approach manifested itself in dialogical forums where stakeholder groups with a political empowerment agenda engaged the local state in participation on a wide range of development issues. The existence of dialogical forums is no longer as prevalent and dominant as they were prior to 1994, but still forms the dominant mode of participation in the preparation of IDPs and provides the backdrop for some types of civic organisations. Education as an organ of state adopted the concept of public participation from the logal governance and coined it to suit their clients.

\section{Participative Management Theory}

It has often been argued that a democratic education system is organised around broad participation in decision-making and the clear accountability of the people in leadership positions and those involved in decision-making. The notion of collegiality became enshrined in the folklore of management as the most appropriate way to run schools and colleges in the 1980s and 1990s (Bush, 2003:64). Collegial model emerged at the time when participative management overpowered bureaucracy and centralised systems in education in many countries worldwide. Collegiality has its roots from the participative management approach of Kurt Lewin (as quoted by Weisbord, 1987:89) believed that "we are likely to modify our own behaviour when we participate in problem analysis and solution and likely to carry out decisions we have helped make".

Among others, it is important to note here that participative management had an improbable origin. It evolved during World War two from collaboration between Lewin and anthropologist Margret Mead in an attempt to reduce civilian consumption of rationed foods (Weisbord, 1987:72). Lewin emphasised the establishment of democratic groups in 
education in which members actively participate in decisions are more productive in terms of both human satisfaction and achievement of goals than authoritarian groups. Participative management includes the idea of inviting people to share into decision-making process. Du Preez (2003:70) advised that participation involves the assignment of decision-making tasks to lower levels. For him, participative decision-making is one of the key features of participative management, whereby all members of the organisation are given an opportunity to make a contribution in the affairs of the organisation and be part of decisions-making process so that they can easily own them. Du Preez (2003:70) posits that joint or participative decision-making will facilitate a pleasant work climate and job satisfaction. Participative decision-making requires mutual understanding and co-operation among participants and becomes more effective when all people get involved in making-decisions that contribute towards the realisation of the organisational goals and objectives. Hence participation leads to empowerment.

At this point, we should mention that when people are encouraged to participate in the organisation' activities they always feel motivated and empowered. According to Davidoff and Lazarus (2002:174), empowerment has two processes, namely, the subjective and the objective empowerment. The first one may refer to a situation where people participate and make inputs in all sections of the organisation while the latter involves the use of power in building structure where people can participate and involve themselves in decision-making processes. Davidoff and Lazarus (2002:175) further asserts that empowerment is fundamentally related to participation, and it is important simply because it is a basic human need to feel a sense of control over your life. As a result of that, empowerment may lead to human satisfaction and enhance a sense of confidence and belonging among individuals in the work place which is the primary aim of participative management. Davidoff and Lazarus (2002:176) conclude by saying when people in any context participate in shaping the life and direction of that situation to satisfy all involving parties. The more the openness, trust, transparency, the more meaningful, people will be able to participate. Therefore, appropriate structures and processes need to be in place to facilitate such participation and control and responsibility needs to be shared.

\section{Education in Democracy}

Notably, education and democracy, as both social contructs, have a symbiotic relationship. While this symbiotic relationship, in general form, dates back to the Plato's and Socrates' era, one could argue that after almost 19 years of democracy, education has transformed for the better, with appalling conditions of schools in other parts of the country are improving with time. Education is and would remain an investment for any developing country, and the success of any country's education system depends to a large extent on the mutual trust and collaboration existing between all partners (Clase et al., 2007:243). The African National Congress (1994:60) envisaged that the public, especially parents in a form of structures like the school governing bodies, will be needed in order to develop the potential of the human resources of the country on assuming leadership position in government. Kallaway (2003:11) agrees to this submission and asserts that education, in whatever form, is a fundamental component of democracy. Through the establishment of SGBs as documented in the SASA Act 84 of 1996, the government was providing the significant amount of power and authority to schools. This decentralisation of education, according to Joubert and Bray (2007:26), is an important wing of democracy as it involves all stakeholders in all education-related issues and regards the principles of public co-operation, public participation, transparency and accountability as imperative.

It could be argued that parental participation is a constitutional obligation ever since the democratic dispensation in South Africa. In many cases, the African National Congress opened arms for the participation of community, especially parents of the learners who are enrolled in that school. The constitution dictates that parents as key stakeholders must be part of decision-making process in all public schools (RSA, 1996). The Act legally provides parents' rights to be involved in school governance. Since 1996, the Republic of South Africa has had a democratic constitution. The constitution is the highest law in the country and all other laws and conducts must be in accordance with the constitution (Potgieter et al., 1995: 5). In fact, the constitution sets out certain important values on which the democratic state is based. In other words, they are values and principles that must be taken into account - also in the governance of schools. The constitution requires that school education be transformed and democratised in accordance with the main values of the constitution. The democratisation of education includes the idea that stakeholders such as parents, teachers and community members beside parents community must participate in the activities of the school.

As part of the process of rebuilding the school system, the South African government passed the South African Schools Act (1996) "in an attempt to give parents the responsibility of managing schools where their children attend and legitimatizing parental participation in the life of the school" (HSRC, 2005: 120). Therefore, The South African Schools Act provides formal power in education to parents as well as communities. It further creates the expectation for parents to 
be meaningful partners in schools governance. Van Wyk (2004:50) sheds light on the abovementioned statement by stating that with the introduction of school governance, the state's intention was to secure a framework of governance that was characterised by power sharing between SGBs and the school management teams (SMTs). However, Christie (2001: 56) asserts that question of school governance and the forms of school community relationships have been a key concern of education policy in South Africa.

The Act requires that schools establish School Governing Bodies (SGB) to be composed of parents, teachers, students (in secondary schools) and members of school support staff (Van Wyk, 2004; HSRC, 2005). The SASA section 23(9) states "The number of parent members must comprise one more than the combined total of other members of a governing body that have voting rights." Only a parent who is not employed at the school may be the chairperson of the governing body (South Africa, 1996, section 29(2); 2001). This shows that the Acts want to empower and encourage parents outside the school premises to be fully involved in the education of their children. Van Wyk (2004: 49) highlighted that "parents have been placed in a powerful position with authority to influence fundamental issues, such as school budget, language policy, discipline, and appointment and promotion of teaching and administrative staff." Furthermore, the SASA stipulates other responsibilities of parents as follows:

- Parents must see to it that a learner attends a school from the first school day of the year in which a learner reaches the age of seven (7);

- Parents must pay the school fees that have been duly approved, expect in the case where a parent has been exempted; and

- Parent's failure to send the child to school without permission may result in a fine or imprisonment.

In concluding this section, we maintain that South African parents and guardians have a critical role to play in the education of their children. Since 1994, they have the main legal responsibility for educating their children. Parents' involvement in school governance becomes only visible through the roles, responsibilities and powers they have in SGBs. The South African Schools Act (1996), section (20) stipulates the functions of all governing bodies of state schools. Even though the functions of School Governing Bodies are clearly set out and visible to all stakeholders, problems concerning the execution of these functions abound. Hence, School Governing Bodies have not been working in an ideal situation. Many issues have been identified and boundaries of responsibilities and capacities have clashed. This is especially the case in rural schools where issues related to governance have been problematic. Some of the problems that local researchers (for example Van Wyk, 2004, Mathonsi, 2004; Ndlazi, 1999) have identified as main issues of concern in rural school governance are power struggle or relations, illiteracy levels and finances.

\section{Parents as Partners}

For us, parents' partnership in education is both a constitutional and policy imperative. National, regional and local educational authorities have a unique obligation to provide basic education for all. But, they cannot be expected to supply every human, financial or organizational requirement for this task. New and revitalized partnerships at all levels will be necessary: partnerships among all sub-sectors and forms of education; partnerships between government and nongovernmental organizations, the private sector, local communities, religious groups and families. Genuine partnerships contribute to the planning, implementing, managing and evaluating of basic education programmes. When we speak of expanded vision and a renewed commitment, partnerships are at the heart of it. Education is, and must be, a societal responsibility, encompassing governments, families, communities and non-governmnetal organizations alike; it requires the commitment and participation of all in a grand alliance that transcends diverse opinions and political positions.

South Africa is a democratic state where everything is executed through the lens of engagement or participation. Education has been crafted within the framework of democratic principles which are clearly articulated in the Bill of Rights (RSA, 1996). That is why parents are key stakeholders in the affairs and management of schools. The implementation of new curriculum represents a change in the learning and teaching approaches. There has been a paradigm shift where focus has shifted from teacher-centred learning to more co-operative learning. This new approach concerns itself with the acquisition of skills and competences instead of collection of theoretical facts and regurgitation of information. This implies a more learner-centred learning approach, which requires commitment of learners as they are expected to execute the greater part of the work. Similarly, the management of school has transformed from an individualistic to a collective form of management known as co-operative management.

It seems likely that in order for them to accomplish this exercise successfully, they may need more resources such as access to internet, journals, books, and many more, but most importantly, they will need parental support. Heystek (as cited in Calitz et al., 1994:112) advises parents, especially those in historically disadvantaged areas, that although they 
may not have the required time and skills to assist their children in this new approach to teaching and learning, their motivation may be crucial. Hoover-Dempsey et al. (2000:3) add that even where parents have recorded doubts about involvement, their misgivings are not related to doubts about their capacity, but often to lack of adequate information. This suggests that the willingness is there, but capacity is lacking. Hoover-Dempsey et al. (2000:3) further submit that parents involve themselves in the school activities because they believe that it is the right thing to do and as such their involvement will make a constructive contribution towards the development of the school. It must be noted that parental involvement covers a wide spectrum ranging from establishing structures for homework performance to teaching, for understanding and developing student learning strategies.

To this end, Kahn and Haupt (2006:113) support these ideas of parental involvement and add that parents' active involvement in school activities such as assisting their children with homework can improve both the academic achievement of children and the relationship between home and the school. Blankstein (2004:167) is also in support of the above submission and argues for the full involvement of students' families and the community at large as he sees it as fundamental to achievement in schools. The participation of stakeholders in partnership should not only be limited to situations when they are needed in carrying out instructions and directives from the educational authorities. The lines of communication should be opened as a matter of policy in order to allow members to make meaningful contributions and also to participate in joint decision-making process. This is in line with what Roda (1994:112-113) regards as the backdrop of support for commitment to quality education.

\section{Challenges and Benefits of Parental Involvement}

History teaches us that parental involvement has never been an easy activity for some communities especially the disadvantaged ones. But close examination shows that parental involvement has always been problematic especially for blacks in rural schools (Ndlazi 1999; Christie 2001; HSRC 2005). The history of parental involvement in rural schools where the majority of people are black is directly linked to apartheid and colonialism of the last century. The reality is that there is no way in which we can turn a deaf ear on the political influence where the kind of participation was centred on the idea of 'education for liberation'. Ndlazi (1999) argues that:

The denial of blacks' participation in political and educational issues brought about by the discriminatory legislation of the apartheid government in South Africa was the major factor in discouraging black parents from being involved in the education of their children. Although black people's rights were very limited in the 1970s and 1980s, some black parents started demanding their right to be involved in the education of their children (1999: 27).

Sayed and Carrim (1997: 91) stressed that demands of decision-making in schools and school governance structures that include all stakeholders concretely manifested themselves in 1980s in the growth and development of Parent Teacher and Student Associations (PTSAs). However, due to apartheid structures, these bodies resulted in individuals nominated by minority white state and consequently, were considered to be illegitimate by the oppressed community (Sayed \& Carrim, 1997: 91).

As a result, the Education and Training Act of 1979 gave School Management Councils (SMCs) the power to govern the traditional black schools at the micro level. Hence, the power of parents was widened giving them a say in matters such as appointments, promotions and dismissals of staff (Ndlazi, 1993: 31). Though the government had passed the Act, some parents seemed reluctant to be members of School Management Councils (SMSs) because SMCs were not fully representative of stakeholders in education. They were seen as puppets of the state since teachers and learners were not involved in the election, which means that the whole process was undemocratic and not transparent.

Our understanding of this issue of parental involvement during the apartheid years is that the system only appeared to be involving parents but in reality the whole system was under the direct control of the apartheid government, their rights were limited, and they could not challenge or criticize its services. Visser (1981:59) argues that the active involvement of parents and communities in the system of education is provided for by means of School Committees, Boards of Control or some other means. However, the School Boards referred to had no powers or rights to challenge the government or school principal. Hence, many parents withdrew and believed that the principal and teachers were the only people responsible for their children's education.

Despite the fact that apartheid and colonialism played a major role in discouraging parental involvement in the governance of South African public schools, the need for change in this area has emerged as a focal point for policy and research. This is because parental involvement is seen as part of the decentralisation of education in the new democratic system. However, the progress of parental involvement in post-apartheid South Africa has not been without its problems. In South African Schools, the Schools Act (RSA, 1996) stipulates that all schools must establish governing bodies on 
which parents have the largest numerical representation (Christie, 2001). Too many, this would have appeared to be a quick solution, but in reality, the notion of governing bodies was a long process which was full of obstacles and challenges, considering the challenges of parental involvement experienced in the past, one might ask why parents must be in education, specifically in school governance.

In summing up, we look into the benefits of parental involvement. Parental involvement in education has many advantages similar to that of other stakeholders such as teachers and learners. Griffith (2000: 162) asserts that involvement of parents in their children's education has long been advocated as integral to positive childhood development and school success. Griffith (2000) adds that the beneficial effects of parent involvement are mostly visible in children's academic learning and performance. Furthermore, Squelch and Lemmer (1994:93) claim parental involvement is vital with benefits such as improving school performance, reducing drop out rates, decreasing delinquency and developing a more positive attitude towards the school. Similarly, Dekker and Lemmer (1993: 165) emphasise that "if the school (and thus education) is to be improved, we need parents who are critical and can make sensible judgements and who do not view changes in the education system as a threat". Again, according to Emerging Voices (HSRC, 2005: 119), "it is important for parents to be involved and supportive of their children's education because children feel encouraged when their parents are informed about their progress at school". Thus, it is clear that it is not desirable to exclude parents from involvement in school governance, particularly when it is their children who are the main clients and potential beneficiaries of educational organisations.

\section{Conclusion}

Participation in education has grown rapidly towards the end of the 21st century and became an interesting subject for debate to many scholars, researchers, educationists, stakeholders and those with interest in educational issues. This article has argued for the value and necessity of parental involvement in the interest of quality public education. It further explored and demonstrated that participation is an important ingredient in the quality of public education which should not be omitted in anyway. Through public participation, we argue that the quality of learners' results would improve and we can also produce responsible citizens and disciplined learners who can be moulded for future leadership positions. If the public is given the recognition it deserves, that will assist in stabilizing education and management of schools. Participative management has some significant features that distinguish it from other forms of management; it encourages co-operation, knowledge sharing, skills identification and capacity building. Finally, participative decisionmaking, empowerment and teamwork are crucial, in addition to common assumed features of a normal organization.

\section{References}

Abbot J. (1996). Sharing the City: Community Participation in Urban Management. Earthscan: Routledge.

African National Congress, (1994). Reconstruction and Development Programme: A policy framework. Johannesburg: Umanyano.

Aucamp, P.J. (2009). Environmental Impact Assessment: A practical guide for the discerning practitioner. Pretoria: Van Schaik Publishers.

Barzelay, M. (2001). The New Public Management: Improving research and Policy Dialogue. Berkeley: University of California Press.

Beetham, D. (1992). Liberal democracy and the limits of democratization. Political Studies, Special Issue, 40-53.

Blankstein, A.M. (2004). Failure is not an option: Six principles that guide student achievement in high -performing schools. California: Corwin.

Birch, D. (2002). Public Participation in Local Government: A survey of local authorities. London: Office of the Deputy Prime Minister.

Bond P. (2001). Against Global Apartheid: South Africa meets the World Bank, IMF and International Finance. Cape Town: University of Cape Town Press.

Bush, T. (2003). Theories of Educational leadership and Management. London: Sage Publication.

Calitz, L.P \& Beckman, J.L. (1994). Guidelines for writing a scription, dissertation or thesis in education. Pretoria: University of Pretoria.

Carrim, Y. (2001). Bridging the gap between the ideas and practice: Challenges of the new local government system.Umrabulo, (10): 26-31.

Clase,P., Kok, J. \& Van der Merwe, M.(2007). Tension between School governing bodies and education authorities in South Africa and proposed Resolution thereof. South African Journal of Education, 27(2): $243-263$.

Christie, P. (2001). Improving School Quality in South Africa: A study of Schools that have succeeded against the odds. South African Journal of Education, 26: 41-65.

Cosser, E. 1991. Education for life. Johannesburg: Creid

Davidoff, S \& Lazarus, S. (2002). The Learning School: An organisational Development Approach. Cape Town: Juta \& Co. Ltd.

Dekker, E. Lemmer, E.M. (1993). Critical issues in modern education.Durban: Butterworths.

Du Preez, P. (2003). Principles of Effective Education Management. A guide to educators and managers in education. Sandown: 
Heinemann.

Dilger, J.D. (1994). Residential Community Associations. New York: New York University Press.

Geddes, M. \& Martin, S.J. (1997): Evaluating local democratic initiatives: Interim Research Report. Warwick University Local Authorities Research Consortium, Working Group on Political Change.

Griffith. J. (2000). Principal's leadership of parent involvement. Journal of Educational Administration, 39(2): 162 - 186.

Hartshorne, K. (1999). The making of education policy in South Africa. Cape Town: Oxford University Press Southern Africa.

Heystek, J. (2004). School Governing Bodies: The Principal's burden or the light of his life? South African Journal of Education, 24(4): $308-312$.

Hoover- Dempsey, K.V., Battiato, A.C., Walker. J.M.T., Reed, R.P., De Jong, J.M. \& Jones, K.P (2001). Parental involvement in homework. Educational Psychologist. 36(3): 1-23.

HSRC. (2005). Emerging Voices: A report on Education in South African Rural Communities. Cape Town: HSRC Press.

Human, P. 1998. Yenza: a blue print for transformation. Cape Town : Oxford University Press Southern Africa.

Joubert, R. \& Bray, E. (2007). Public School Governance in South Africa. Inter-University Centre of Education Law and Education Policy (CELP), University of Pretoria.

Kallaway, P. (2003). Government, Not Schools, To blame for Crisis. Cape Times, May 29, 2003, p 3.

Khan, Z. \& Haupt, T. (2006). Community participation- a necessary element of community development projects. Acta Stuctilia, 13(2): 39-61.

Kooiman J. (1993): Modern Governance: New Government Society Interaction. London: Sage

Mathonsi, V. (2004). Democratization of School Education. The Educator's Voice, 8(1): p20 Maile, S. (2002). Accountability: An essential aspect of School governance. South African Journal of Education. 22(4): 326-331.

Midgley, J., Hall, A., Hardiman, M. \& Narine, D. (1986). Community Participation, Social Development and the State. London: Methuen. Molopo, M.M. (2000). Parental empowerment in the democratisation of education. Journal of Education and Training, 21(2): 70-85.

Mayekiso M. (1996). Township Politics: Civic struggles for a new South Africa. New York: Monthly Review Press.

Ndlazi, S.M. (1999). An investigation of parental non -involvement in the governance of a Duncan Village school and its implications for the management of the school: A case study. Unpublished Master's Treatise. Rhodes University: Grahamstown.

Osborne, D \& Gaebler, T. (1993). Reinventing Government: How the entrepreneurial spirit is transforming the public sector. Reading, MA: Addison-Wesley.

Potgieter, J.M. Visser, P.J. Van der Bank, A.J. Mothata. M.S. \& Squelch, J.M. 1996. Understanding the South African School's Act. What Public School Governors need to know. Pretoria: Department of Education.

Republic of South Africa. (1996). South Africa School Act, Act 84 of 1996. Pretoria: Government Printer.

Roberts, N. (2003). Direct Citizen Participation: Building a Theory. Paper presented to the $7^{\text {th }}$ National Public Management Research Conference held at the Georgetown University. Washington D.C. on 9-11 October

Roda, J. (1994). Leadership in early Childhood :pathway to professionalism. Sydney: Teacher College Press.

Sayed, Y. \& Carrim, N. (1997). Democracy, participation and equity in educational governance. South African Journal of Education, 17(3): $91-100$.

Seekings, J. (2000). The UDF: A history of the United Democratic Front in South Africa 1983-1991.

Squelch, J. \& Lemmer, E. (1994). Eight keys for effective School management in South Africa. Halfway House: Southern Book Publishers.

Unesco. (2009). Promoting participation: Community contributions to education in conflict situations. New York: United Nations.

United Nations. (1981). Popular Participation as a Strategy for Planning Community Level Action and National Development. New York: United Nations.

Van Wyk, N. (2004). Scool Governing Bodies: The experiences of South African Educators. South African Journal of Education, 42(1): $49-54$

Van Wyk, N. \& Lemmer, E. (2009). Organising Parent Involvement in South African Schools. Cape Town: Juta \& Company.

Visser, A.J.J. (1981). Education in Namibia (South West Africa): A 1980 perspective).South African Journal of Education, 1(1/2): 57-60.

Weisbord, M.R. (1987). Productive workplaces. Organising and managing for dignity, meaning, and community. San Francisco: Jossey Bass.

Wood, C. (2003). Environmental Impact Assessment - A comparative review. Harlow: Pearson Education Ltd.

World Bank Participation Source Book. (1995). Social Policy and Resettlement Division. Washington, D.C.: World Bank. 
